\title{
Efisiensi Teknis Bank Pembangunan Daerah di Indonesia Periode Tahun 2009 sampai dengan 2011
}

\author{
Atman Poerwokoesoemo ${ }^{1}$
}

\begin{abstract}
The purpose of this research is to measure the technical efficiency of the 26 Rural Development Bank in Indonesia for 2009 to 2011 based on Farrel's method and implementing the assumption of the efficient production continuous function to take the form of Cobb-Douglas production function. Technical efficiency measured involving two input variable; Capital and Total Employee and one output variable Loan.

The result of this research shows that the Cobb-Douglass parameter $\alpha=0.683$ dan $\beta=$ 0.317. Among the 26 Rural Development Bank shows that 2 banks consistently maintain its technical efficiency level in the range of 80 to 100\%, 2 banks maintains its technical efficiency level in the range between 60 to $80 \%, 13$ banks lays below $60 \%$ and the remaining 9 banks are moved up and down along the three years period.
\end{abstract}

Key word: Technical Efficiency, Capital, Employee, Loan

\section{PENDAHULUAN}

Konsep efisiensi produksi dalam ilmu ekonomi dan dunia industri sangat penting karena efisiensi merupakan bagian dari ukuran kinerja suatu perusahaan atau unit produksi atau unit pengambil keputusan. Efisiensi berkaitan erat dengan sejauh mana suatu industri atau organisasi tertentu berhasil mengelola sumberdaya yang dimilikinya guna menghasilkan output yang maksimal. Sekalipun demikian pengukuran efisiensi suatu unit pengambil keputusan tidaklah semudah pengukuran dalam dunia engineering. Pada umumnya suatu unit pengambil keputusan dapat menghasilkan satu atau lebih jenis output dan untuk menghasilkannyapun melibatkan pemanfaatan lebih dari satu jenis input.

Untuk tujuan itu dikembangkanlah beragam pengertian efisiensi dan metode pengukurannya. Terdapat tiga pengertian efisiensi yang lazim, dimana efisiensi yang pertama adalah efisiensi ekonomis (economic efficiency) atau sering juga disebut dengan istilah efisiensi keseluruhan (overall efficiency) yang merupakan komposisi dari efisiensi teknis (technical efficiency) dan efisiensi alokasi (allocative efficiency). Efisiensi teknis mengacu kepada konversi input menjadi output relatip terhadap "best practice", dimana pengertian "best practice" 
direpresentasikan sebagai frontier effisien. Efisiensi teknis kurang bermakna dalam ekonomi karena tidak terkait dengan harga input (input price). Sedangkan efisiensi alokasi mengacu kepada bagaimana suatu input - pada tingkat output tertentu dan harga input tertentu - dipilih untuk menghasilkan biaya produksi minimal dengan asumsi bahwa organisasi bersangkutan efisien secara teknis (Bhagavad,

Upaya metodik dalam mengukur efisiensi diawali oleh pekerjaan Farrel (1957) kemudian berkembang pada dua metode pengukuran dengan basis yang berbeda yaitu 1) metode parametrik yang dikembangkan oleh Aigner, Lovell \& Schmidt (1977) menggunakan pendekatan statistik yang lazim disebut stochastic frontier analysis (SFA) dan 2) metode non parametrik yang diwakili oleh model data envelopment analysis (DEA) yang dikembangkan oleh Charness, Cooper \& Rhodes (1978) menggunakan pendekatan optimasi programasi linier. Kedua metode ini sekalipun berbeda namun keduanya sejatinya memiliki tujuan yang sama yaitu menentukan frontier efisien pada mana nantinya setiap organisasi dalam sampel diukur tingkat efisiensi relatip terhadap frontier ini. Kedua metode ini banyak dipergunakan untuk mengukur tingkat efisiensi pada berbagai jenis organisasi komersial maupun non komersial.

Penelitian ini berupaya meninjau kembali ke titik awal pengembangan konsep efisiensi yang dikembangkan oleh Farrel (1957). Farrel memandang efisiensi teknis suatu unit pengambil keputusan didasarkan kepada kedudukan geometris relatip unit terukur tersebut terhadap suatu frontier efisien. Makin dekat kedudukan geometris relatip suatu unit terukur makin efisien unit tersebut secara teknis. dan sebaliknya makin jauh makin kurang efisien. Adapun frontier efisien itu sendiri dibangun per definisi oleh Farrel (1957), Charness, Cooper \& Rhodes (1978) maupun Lovel, Aigner \& Schmidt (1976) sebagai segmen - segmen garis (dalam ruang dua dimensional) atau permukaan (dalam ruang tiga dimensional atau lebih) yang melingkupi sejumlah unit pengambil keputusan dalam suatu kumpulan sampel sedemikian hingga tidak ada unit pengambil keputusan yang berada di luar lingkup tersebut. Dalam penelitian ini, dengan tetap tidak keluar dari ide dasar efisiensi teknis Farrel (1957), alih - alih mendefinisikan segmen - segmen garis frontier efisien atau permukaan, kita akan mendefinisikan suatu fungsi frontier efisien yang kontinu.

Penelitian ini bertujuan menguraikan pengukuran efisiensi teknis dengan terlebih dulu mendefinisikan frontier efisien sebagai suatu fungsi kontinu kemudian mengimplementasikannya untuk mengukur tingkat efisiensi teknis relatip dari 26 Bank Pembangunan Daerah (BPD) di Indonesia antara periode 2009 hingga 2011.

Tulisan ini dibagi dalam dua bagian. Bagian pertama akan dibahas tentang konsep pengukuran efisiensi teknis menggunakan frontier efisien sebagai sebuah fungsi kontinu mengacu model Cobb - Douglas dan pada bagian kedua akan dibahas implementasi pengukuran efisiensi teknis terhadap 26 BPB di Indonesia periode 2009 sampai dengan 2011.

\section{TINJAUAN PUSTAKA}

\section{Pengukuran Efisiensi Teknis Model Farrel}

Adalah sebuah gagasan menarik untuk meningkatkan produksi dengan semata-mata hanya meningkatkan efisiensi produksi tanpa penambahan jumlah input-input yang terlbat. Persoalannya adalah bagaimana mengukur efisiensi yang tepat, Farrel (1957) mengusulkan suatu metode pengukuran efisiensi teknis. 
Farrel (1957) secara umum efisiensi teknis diartikan sebagai keberhasilan untuk memperoleh output maksimal dari pemanfaatan sejumlah input tertentu. Untuk dapat mengukur efisiensi suatu unit produksi, fungsi produksi efisien (efficient production function) harus terlebih dahulu diketahui dengan baik. Fungsi produksi efisien adalah jumlah output yang bisa diperoleh dari suatu unit produksi yang efisien sempurna dari setiap kombinasi input yang digunakan.

Dengan demikian maka untuk mengukur efisiensi teknis suatu unit produksi terlebih dahulu harus diketahui fungsi produksi efisien unit produksi bersangkutan dan selanjutnya efisiensi teknis suatu unit produksi akan diperoleh dengan membandingkan output suatu unit produksi (pada suatu kombinasi input tertentu) terhadap output yang bisa dihasilkan oleh unit produksi yang dianggap efisien sempurna. Dalam penelitian Farrel (1957) dan juga dalam penelitian ini, fungsi produksi efisien akan ditentukan dari data pengamatan terhadap sejumlah unit produksi.

Untuk menentukan mensederhanakan persoalan misalkan bahwa suatu unit ptoduksi memanfaatkan dua jenis input yaitu input modal $\mathrm{K}$ dan input tenaga kerja $\mathrm{L}$ dan menghasilkan satu jenis output Y. Selanjutnya fungsi produksi efisien diasumsikan bahwa setiap unit produksi dapat direpresentasikan sebagai suatu titik dalam diagram isoquant dimana setiap titik menyatakan kombinasi input $\mathrm{K}$ dan input $\mathrm{L}$. Oleh karenanya bila terdapat $\mathrm{N}$ buah unit produksi yang diamati akan membentuk sebaran $\mathrm{N}$ buah titik dalam diagram isoquant. Diasumsikan juga bahwa fungsi produksi efisien harus berbentuk konveks dan memiliki slope tidak positip dimanapun karena bila tidak maka setiap penambahan input akan menyebabkan penurunan output. Pemilihan input $\mathrm{K}$ dan $\mathrm{L}$ semata-mata mengikuti prosedur yang dilakukan oleh Farrel (1957). Pada kenyataannya setiap jenis produksi dapat melibatkan lebih dari dua jenis input dan atau menghasilkan lebih dari satu output. Kelak metode Data Envelopment Analysis yang dikembangkan oleh Charnes, Cooper \& Rhodes (1978) memunginkan dilakukannya perhitungan efisiensi dengan melibatkan multi input dan multi output.

Misalkan kita mengamati $\mathrm{N}$ buah unit produksi yang menggunakan input tenaga kerja $L$ dan inut modal $\mathrm{K}$ sehingga kita memiliki himpunan $\mathrm{N}$ dari $\mathrm{N}$ buah titik amatan $A=$ $\left\{\left(K_{i}, L_{i}\right), i=1,2,3, \ldots, N\right\}$.

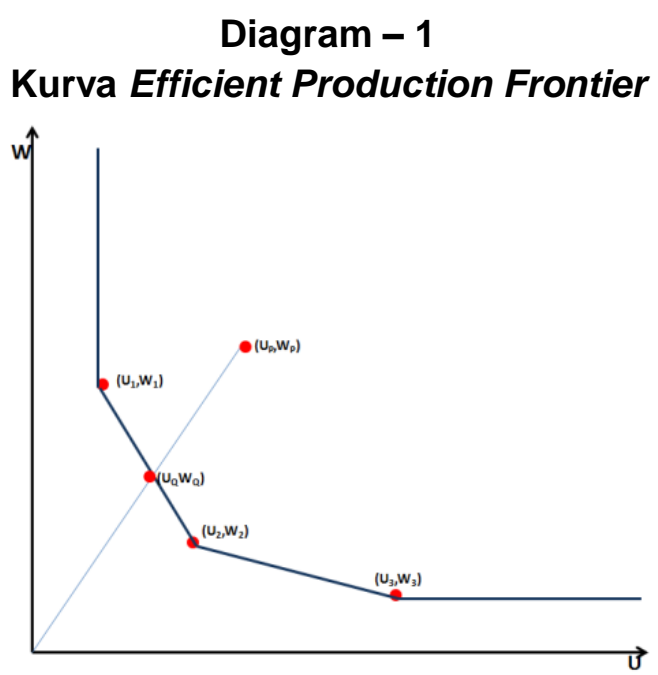

Selanjutnya Farrel (1957) mendefinisikan bahwa isoquant efisien terdiri dari serangkaian segmen-segmen garis yang menghubungkan himpunan titik-titik pengamatan tertentu $B=$ $\left\{\left(K_{k}, L_{k}\right), k=1,2,3, \ldots, M \leq N\right\} \subset A$ dan titik $(0, \infty)$ dan $(\infty, 0)$ dengan setiap segmen garis memenuhi syarat : (1) slope (gradien) segmen garis yang selalu positip, (2) tidak ada titik 
pengamatan yang terletak antara segmen garis tersebut dan titik awal koordinat pada mana isoquant didefinisikan. Secara aljabar kita dapat nyatakan syarat diatas sebagai berikut: jika segmen $X$ dibangun oleh $P_{1}=\left(K_{1}, L_{1}\right), P_{2}=\left(K_{2}, L_{2}\right) \in B$ dan $P_{k}=\left(K_{k}, L_{k}\right) \in B$ terletak pada segmen $X$ maka

$\lambda_{12 k} K_{1}+\mu_{12 k} K_{2}=K_{k}$

$\lambda_{12 k} L_{1}+\mu_{12 k} L_{2}=L_{k}$

dan akan memberikan : (1) $\lambda_{12}+\mu_{12}=1$ (lihat Lampiran 1) bila $P_{k}=\left(K_{k}, L_{k}\right) \in B$ terletak pada segmen $X$, (2) $\lambda^{*}{ }_{12 k}+\mu^{*}{ }_{12 k}>1$ bila segmen $X$ terletak antara $P_{k}=\left(K_{k}, L_{k}\right) \in B$ dan titik awal koordinat pada mana isoquant didefinisikan. Dari sini dapat didefinisikan efisiensi teknis $P_{k}$ sebagai perbandingan antara jumlah bobot pada fungsi produksi efisien dimana $\lambda_{12}+\mu_{12}=1$ (best practice) dengan jumlah bobot titik $P_{k}$ yaitu $\lambda_{12 k}^{*}+\mu_{12 k}^{*}>1$ yang senantiasa akan diperoleh

$\eta_{k}=\frac{\lambda_{12}+\mu_{12}}{\lambda^{*}{ }_{12 k}+\mu^{*}{ }_{12 k}}=\frac{1}{\lambda^{*}{ }_{12 k}+\mu^{*}{ }_{12 k}}<1$

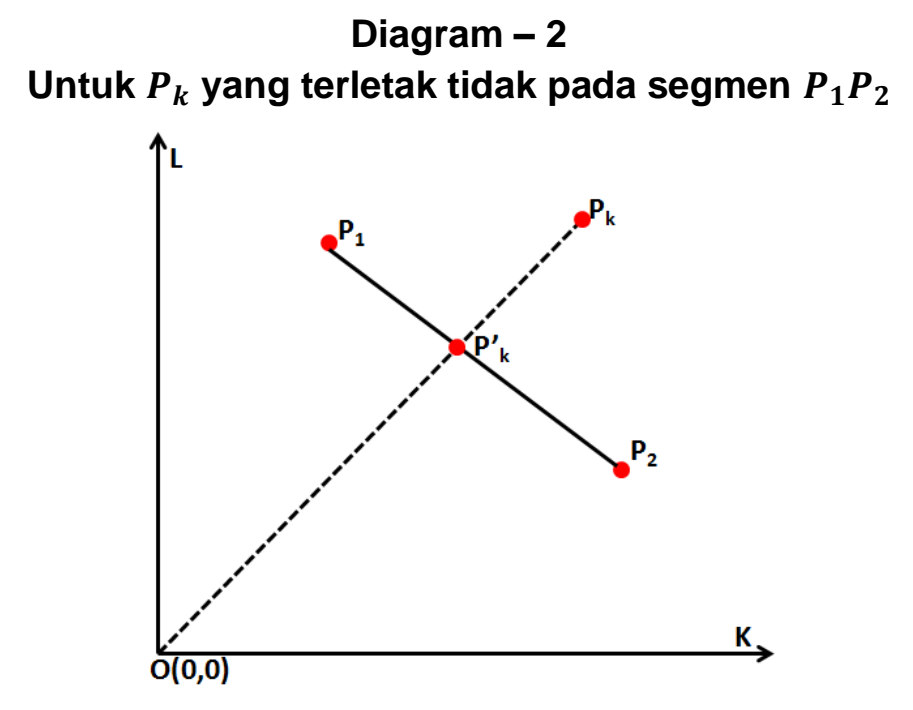

Metode ini dapat memberikan nilai efisiensi suatu unit produksi tanpa mendefinisikan fungsi produksi efisien yang direpresentasikan oleh serangkaian segmen-segmen garis yang menghubungkan himpunan titik-titik pengamatan tertentu $B=\left\{\left(K_{k}, L_{k}\right), k=1,2,3, \ldots, M \leq N\right\} \subset A$ dan titik $(0, \infty)$ dan $(\infty, 0)$.

\section{Efisiensi Teknis Model Cobb - Douglas}

Bilamana Farrel (1957) menggunakan gabungan segmen garis sebagai representasi efficient production frontier maka dalam penelitian ini efficient production frontier akan diasumsikan mengambil bentuk fungsi kontinu dengan dua input dan satu output yang mengikuti model Cobb-Douglas pada bidang yang dibatasi oleh $Y=1$ yaitu

$$
Y=F\left(U_{j}, W_{j}\right)=A U_{j}^{\alpha} W_{j}^{1-\alpha}=1
$$


dimana $U_{j}$ adalah jumlah input modal $K$ unit ke - $j$ untuk menghasilkan 1 unit output dan $W_{j}$ adalah jumlah input tenaga kerja $L$ unit ke - $j$ untuk menghasilkan 1 unit output sedangkan $A$ adalah faktor produktivitas. Sementara $\alpha$ dan $\beta$ adalah parameter yang akan dicari. Persamaan (03) dapat kita tuliskan $W$ sebagai fungsi dari $U$

$W_{j}\left(U_{j}\right)=A^{-\frac{1}{1-\alpha}} U_{j}^{-\frac{\alpha}{1-\alpha}}$

Selanjutnya, kini kita definisikan variabel baru

$W_{j} \equiv R_{j} \frac{k_{j}}{\sqrt{1+k_{j}^{2}}}$

$U_{j} \equiv R_{j} \frac{1}{\sqrt{1+k_{j}^{2}}}$

dimana

$R_{j}=\left(U_{j}^{2}+W_{j}^{2}\right)^{1 / 2}$

adalah jarak dari titik awal sistem koordinat kepada kedudukan unit ke - $j$ dimana

$k_{j}=\tan \theta_{\mathrm{j}}=\frac{W_{j}}{U_{j}}$

adalah sudut yang dibangun oleh garis $R_{j}$ dan sumbu horizontal $U$ sistem koordinat. Dan $k_{j}$ adalah perbandingan faktor input tenaga kerja $W_{j}$ terhadap faktor input modal $U_{j}$ Selanjutnya bila (05) disubstitusikan pada (04) kita akan mendapatkan efficient production frontier.

$R_{j}=A^{-1}\left[k_{j}\right]^{-(1-\alpha)} \sqrt{1+k_{j}^{2}}$

Karena dalam ekonomi kita hanya berurusan input dan output bernilai positip maka harga $k_{j} \in[0, \infty]$ atau harga $\theta \in\left[0, \frac{1}{2} \pi\right]$. Kini kita memiliki efficient production frontier dalam $R$. Keunikan efficient production frontier ini terletak pada koefisien produktivitas $A$. Dua kombinasi input dengan harga $k$ yang sama akan memberikan harga $R$ berbeda pada harga $A$ yang berbeda. Untuk memperoleh harga $A$ kita akan memanfaatkan persamaan (03) untuk mendapatkan bentuknya yang paling sederhana

$R_{j}=U_{j}\left(1+k_{j}^{2}\right)^{\frac{1}{2}}$

Untuk memperoleh harga $A$ bagi efficient production frontier diperoleh dengan mengambil

$\max \left(\left\{A_{j}\right\}\right)=\max \left(\frac{1}{U_{j}{ }^{\alpha} W_{j}^{1-\alpha}}\right)$

terhadap sampel. Kemudian menggunakan (09) kita akan dapat menghitung jarak radial $R_{e j}$ dari titik awal koordinat ke kurva efficient production frontier untuk setiap harga $k_{j}$ yaitu

$R_{e j}=\left[\max \left\{\frac{k_{j}}{W_{j}}\right\}\right]^{-1}\left[k_{j}\right]^{-(1-\alpha)} \sqrt{1+k_{j}^{2}}$

Persoalan yang tersisa adalah penentuan parameter $\alpha$ dan $\beta$ yang membentuk efficient production frontier. Dalam menetapkan parameter $\alpha$ dan $\beta$ diasumsikan bahwa fungsi produksi 
berlaku constant return to scale (CRS) sehingga dalam penyusunan model regresi dikenai kendala $\beta=1$ - $\alpha$ dan model regresi mengambil bentuk

$\ln \left(\frac{Y_{j}}{L_{j}}\right)=C_{0}+C_{1} \ln \left(\frac{K_{j}}{L_{j}}\right)$

Selanjutnya efisiensi teknis $\eta_{j}$ dihitung dengan menggunakan persamaan (07) dan

$\eta_{j}=\frac{R_{e j}}{R_{j}}=U_{j}^{-1}\left[\max \left\{\frac{k_{j}}{w_{j}}\right\}\right]^{-1}\left[k_{j}\right]^{-(1-\alpha)}$

Persamaan (13) menunjukkan perbandingan antara jarak radial kedudukan titik unit yang diukur kepada titik awal koordinat terhadap jarak radial kedudukan kurva efficient production frontier kepada titik awal koordinat yang memiliki makna fisis yaitu perbandingan antara konversi input menjadi output (diwakili oleh $R_{j}$ ) relatip terhadap "best practice" (diwakili oleh $R_{e}$ ). Karena letak titik yang diukur senantiasa disisi kanan atas kurva maka harga $R_{e j}<R_{j}$ maka harga $\eta \in$ $[0,1]$

\section{PENELITIAN TERDAHULU}

Sejumlah penelitian tentang pengukuran efisiensi menggunakan kedua jenis pendekatan yaitu parametrik maupun non parametrik telah dilakukan di banyak negara oleh banyak peneliti dengan obyek penelitian yang beragam. Penelitian efisiensi berbasis Stochastic Frontier Analysis telah dilakukan oleh Aigner, Lovell \& Schmidt (1977), sedangkan untuk penelitian yang berbasis Data Envelopment Analysis dilakukan oleh Angelidis, Lyroudi (2006). Di Indonesia penelitian efisiensi berbasis Data Envelopment Analysis dilakukan antara lain oleh Abidin (2007) dan Sutawijaya \& Lestari (2009).

\section{METODE PENELITIAN}

Penelitian ini adalah penelitian deskriptif kuantitatif dengan tujuan mengukur efisiensi teknis menggunakan pendekatan geometri dengan obyek Bank Pembangunan Daerah (BPD). Populasi BPD berjumlah 26 bank tersebar diseluruh Indonesia. Data diperoleh dari Annual Report dari obyek (yang dipublikasi melalui situs resmi Bank Indonesia (BI) dan Otoritas Jasa Keuangan (OJK) untuk tahun 2009, tahun 2010 dan tahun 2011.

Penelitian ini menggunakan dua variabel input adalah variabel Modal $(K)$ dan variabel Tenaga Kerja $(L)$, sedangkan variabel output adalah Kredit Yang Diberikan sebelum dikurangi dengan pos Penyisihan Penghapusan Aktiva Produktip $(Y)$. Dalam berbagai penelitian variabel Modal $(K)$ biasanya adalah jumlah asset tetap dalam pos aset tetap dan variabel Tenaga Kerja $(L)$ adalah jumlah orang-jam kerja dalam setahun. Dalam penelitian ini variabel Modal $(K)$ menggunakan jumlah modal disetor dengan asumsi bahwa bank-bank di Indonesia pada umumnya menggunakan gedung kantor cabang adalah gedung sewa yang tidak tercermin dalam aset tetap. Sedangkan variabel Tenaga Kerja menggunakan jumlah tenaga kerja dengan asumsi bahwa jumlah jam kerja per orang per tahun adalah sama, sehingga variabel Tenaga Kerja $(L)$ dapat diwakili oleh jumlah tenaga kerja saja. Dalam penelitian (Hasan, Kamil, Mustafa \& Baten, 2012) variabel input yang digunakan adalah Simpanan Berjangka dan Biaya Overhead dengan output Total Aset Produktif. 
Pengolahan data dilakukan dalam tiga tahapan yaitu: 1) menggunakan data Modal $\left(K_{j}\right)$, Tenaga Kerja $\left(L_{j}\right)$ dan Kredit Yang Diberikan $\left(Y_{j}\right)$ dilakukan penghitungan: a) faktor input Modal $\left(U_{j}=K_{j} / Y_{j}\right)$ dan faktor input Tenaga Kerja $\left(W_{j}=L_{j} / Y_{j}\right)$ dan b) dilakukan regresi linier dengan model (12) untuk memperoleh parameter $\alpha$ dan $\beta$, 2) menghitung harga $\max \left(\left\{A_{j}\right\}\right)=$ $\max \left(\frac{1}{U_{j}{ }^{\alpha} W_{j}{ }^{1-\alpha}}\right)$ menggunakan persamaan (08). Hasil yang diperoleh adalah kurva efficient production frontier dan 3) menghitung $R_{e}$ menggunakan (11), $R_{j}$ untuk $j=1,2,3, \ldots, N$ menggunakan (09) dan menghitung tingkat efisiensi teknis $\eta_{j}$ menggunakan (13).

\section{HASIL ANALISIS}

Obyek penelitian ini adalah Bank Pembangunan Daerah (BPD) di Indonesia dengan jumlah populasi 26 bank dengan data keuangan dan non keuangan berasal dari Laporan Tahunan Bank periode tahun 2009 sampai dengan tahun 2011 (3 tahun) yang sudah diunggah di web site Bank Indonesia dan Otoritas Jasa Keuangan. Data dimaksud disajikan dengan urutan modal terkecil hingga modal terbesar pada Lampiran 2 Tabel-1. Dan dalam variabel U dan W pada Lampiran 2 Tabel-2.

Terdapat dua variabel input yang digunakan yaitu 1) Modal $(K)$ yaitu jumlah modal disetor dan 2) Tenaga Kerja $(L)$ yaitu jumlah tenaga kerja. Sedangkan variabel output yang dipilih yaitu Kredit yang diberikan $(Y)$. Pemilihan Kredit yang diberikan sebagai output dengan pertimbangan bahwa Kredit merupakan a) portfolio aset produktif terbesar bank, dan b) merupakan sumber pendapatan terbesar bank baik dalam bentuk interest income maupun fee based income.

Regresi linier dengan menggunakan model (12) yaitu $\ln \left(K L_{j}\right)=C_{0}+C_{1} \ln \left(C L_{j}\right)$ dimana

variabel $K L_{j} \equiv \frac{Y_{j}}{L_{j}}$ dan $C L_{j} \equiv \frac{K_{j}}{L_{j}}$ diperoleh hasil $\ln \left(K L_{j}\right)=1845.389+0.683 \ln \left(C L_{j}\right)$. Selanjutnya dengan hasil regresi diatas kita memperoleh harga parameter $\alpha=0.683$ dan parameter $\beta=1-$ $\alpha=1-0.683=0.317$. Penggunaan regresi linier ini mengadopsi (Felipe \& Adams, 2005) Menggunakan harga parameter $\alpha$ (hasil regresi pada Lampiran 3) kita akan menghitung $\max \left(\left\{A_{j}\right\}\right), k_{j}, R_{j}, R_{e j}$ dan tingkat efisiensi relatip $\eta_{j}$ yang hasilnya dapat dilihat pada Lampiran 4.

Dari populasi yang digunakan dalam penelitian ini diperoleh harga $A_{j}$ merentang antara 75.5002 (BPD 19 tahun laporan 2009) hingga 246.9896 (BPD 13 tahun laporan 2009). Dengan demikian harga $\max \left(\left\{A_{j}\right\}\right)=246.9896$. Harga $k_{j}$ berada pada rentang antara 0.0020 (BPD 26 tahun laporan 2011) dan 0.0210 (BPD 3 tahun laporan 2009) dengan $k_{j}$ rata-rata 0.0070. Harga $R_{j}$ berada pada rentang antara 0.0173 (BPD 3 tahun laporan 2009) dan 0.0821 (BPD 25 tahun laporan 2011). Adapun harga $R_{e j}$ berada pada rentang antara 0.0138 (BPD 3 tahun laporan 2009) dan 0.0289 (BPD 26 tahun laporan 2011). Dan nilai efisiensi teknis relatip berada pada rentang 0.2935 (BPD 19 tahun laporan 2009) hingga yang paling efisien dengan nilai efisiensi 1.000 (BPD 13 tahun laporan 2009). 


\section{Grafik-1}

Kurva Frontier Efisien dan Sebaran Data Populasi

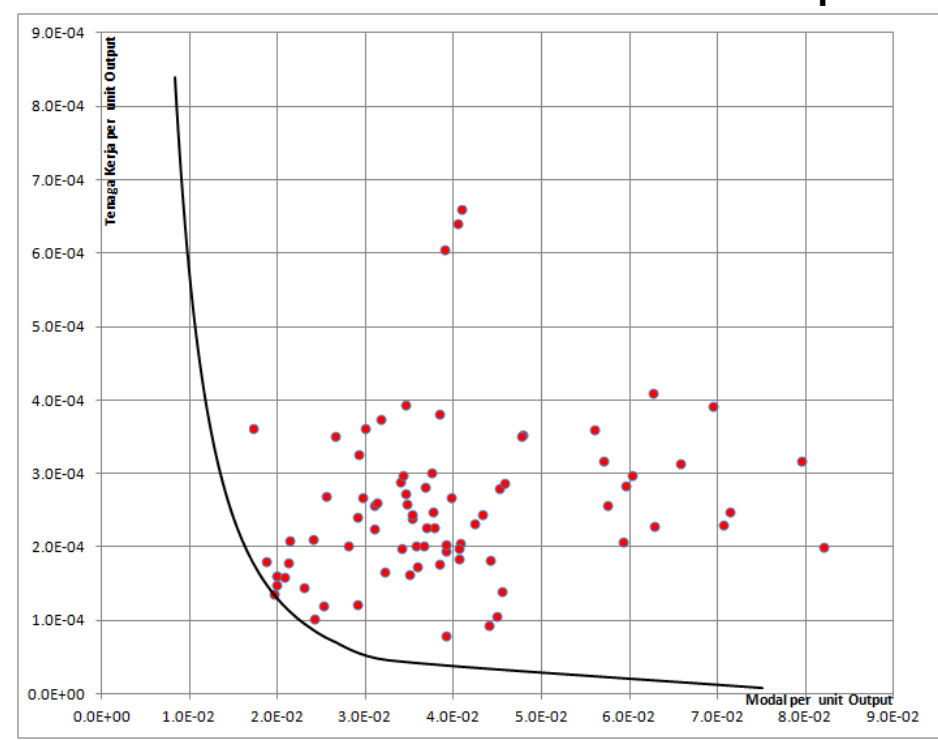

Unit produksi yang memiliki nilai efisiensi maksimum adalah BPD 13 untuk tahun laporan 2009 dengan $k_{j}=0.0070$ dan $R_{j}=0.0195$. Selain BPD 13 tersebut, bank dengan harga $k_{j}$ yang sama namun dengan harga $R_{j}$ yang berbeda dengan unit produksi efisien adalah BPD 12 tahun laporan 2011. Pada BPD 12 tahun laporan 2011 memiliki harga $R_{j}=0.0353$, artinya bahwa kedua bank yaitu BPD 12 tahun laporan 2011 dan BPD 13 tahun laporan 2009 menggunakan kombinasi faktor input yang sama (pada jumlah input yang berbeda) menghasilkan output yang sama yaitu 1 satuan output.

Perbedaan ini memberikan nilai efisiensi teknis yang berbeda. BPD 12 tahun laporan 2011 adalah $\eta_{j}=0.5544$ sedangkan BPD 13 tahun laporan 2009 memiliki nilai efisiensi $\eta_{j}=1.0000$.

Ditinjau dari kesamaan $R_{j}$, BPD 17 tahun laporan 2010 dan BPD 18 tahun laporan 2010 memiliki harga $R_{j}=0.0290$ namun memiliki harga $k_{j}$ yang berbeda. BPD 17 tahun laporan 2010 memiliki $k_{j}=0.0083$ sedangkan BPD 18 tahun laporan 2009 memiliki $k_{j}=0.0042$. Perbedaan ini menghasilkan nilai efisiensi teknis berbeda, BPD 17 tahun laporan 2010 adalah $\eta_{j}=0.6379$ sedangkan BPD 18 tahun laporan 2009 memiliki nilai efisiensi $\eta_{j}=0.7911$. 


\section{Grafik-2}

\section{Perbandingan Frontier Efisien Kontinu dan Segmen (Farrel)}

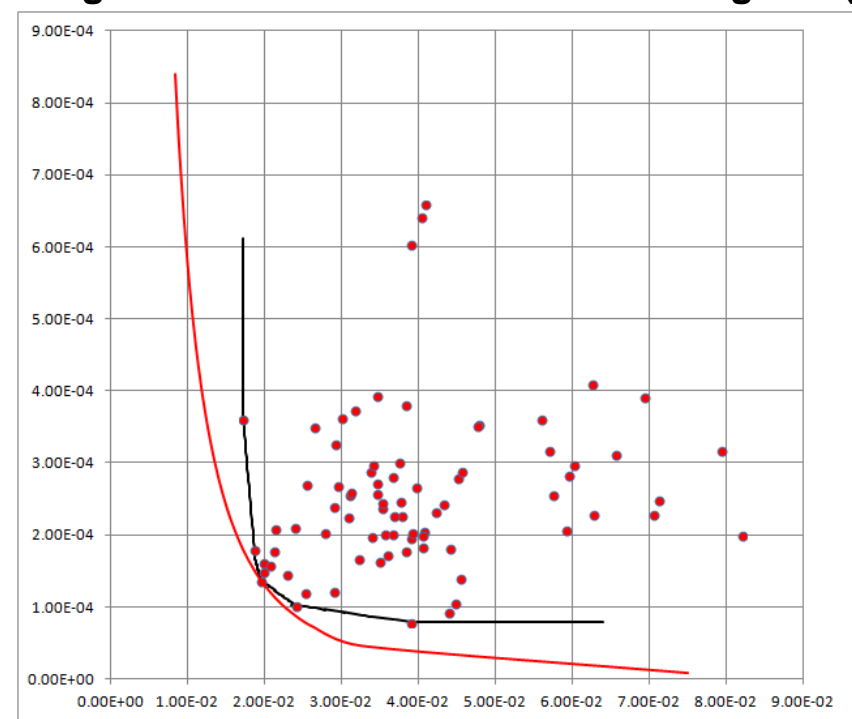

Bila hasil pengukuran efisiensi dikelompokkan dalam tiga kelompok yaitu: kelompok BPD dengan nilai efisiensi teknis diatas $80 \%$, kelompok BPD dengan nilai efisiensi teknis antara $60 \%$ sampai dengan $80 \%$ dan kelompok BPD dengan nilai efisiensi teknis diatas $80 \%$ maka diperoleh :1) terdapat 10 BPD-tahun laporan dengan nilai efisiensi teknis antara $80 \%$ sampai dengan $100 \%$, 2) terdapat 16 BPD-tahun laporan dengan nilai efisiensi teknis antara $60 \%$ sampai dengan $80 \%$ dan 3) terdapat 52 BPD-tahun laporan dengan nilai efisiensi teknis dibawah $60 \%$.

Dari pengelompokan tersebut terdapat 2 BPD yang secara konsisten berada pada kelompok dengan tingkat efisiensi antara $80 \%$ sampai dengan $100 \%$ selama 3 tahun berturutturut yaitu BPD 13 dan BPD 14, kemudian terdapat 2 BPD yang secara konsisten berada pada kelompok dengan tingkat efisiensi antara $60 \%$ sampai dengan $80 \%$ selama 3 tahun berturut-turut yaitu BPD 17 dan BPD 26, dan selanjutnya terdapat 13 BPD yang secara konsisten berada pada kelompok dengan tingkat efisiensi dibawah $60 \%$ selama 3 tahun berturut-turut. Dengan demikian terdapat 9 BPD yang mengalami perpindahan kelompok tingkat efisiensi teknis selama 3 tahun tersebut.

Sekalipun bukan merupakan bagian dari tujuan penelitian ini namun pada bagian akhir ditampilkan perbandingan dengan metode yang dipergunakan Farrel (1957) menunjukkan ada satu titik yang memberikan nilai efisiensi sama yaitu BPD 13 tahun laporan 2009 yang memiliki nilai efisiensi satu dengan $R_{j}=0.0195$, dan $k_{j}=0.0070$. 


\section{Grafik-3}

\section{Perbandingan 3 Frontier}

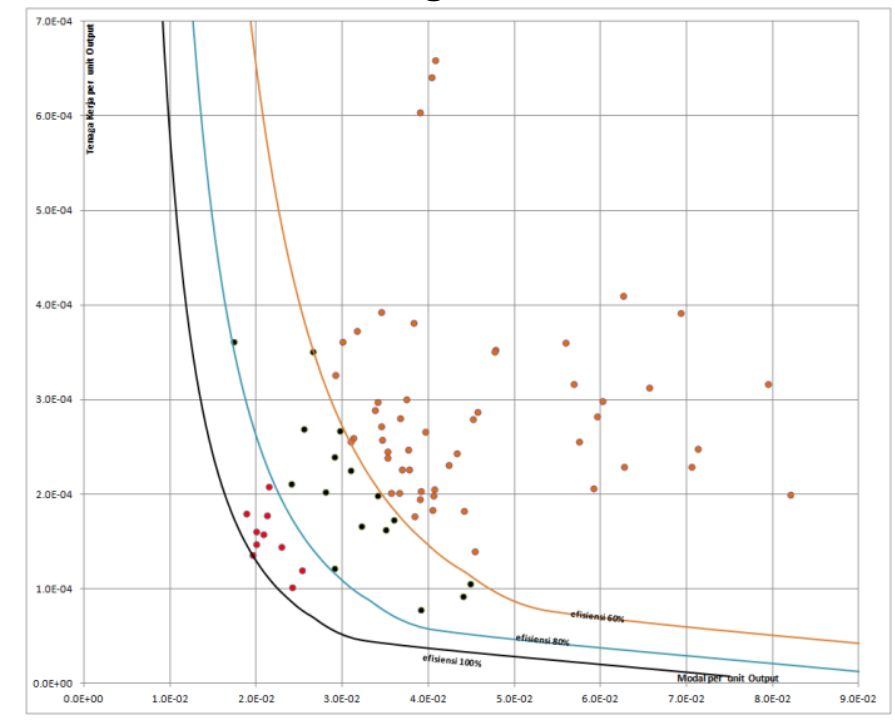

\section{SIMPULAN DAN SARAN}

\section{Simpulan}

Dari penelitian ini dapat disimpulkan bahwa efisiensi teknis unit pengambil keputusan yang dalam hal ini adalah BPD di seluruh Indonesia dapat diperoleh dengan mengukur jarak relatip suatu unit pengambil keputusan terhadap kurva fungsi kontinu efficient productive frontier dimana ada 1 bank BPD yang dinyatakan efisien secara teknis. BPD ini adalah BPD 13 tahun laporan 2009 dengan harga $k_{j}=0.0070$ dan harga $R_{j}=0.0195$. 2 bank BPD konsisten selama 3 tahun berturut-turut berada dalam kategori nilai efisien secara teknis antara $80 \%$ sampai dengan $100 \%$, 2 bank BPD konsisten selama 3 tahun berturut-turut berada dalam kategori nilai efisien secara teknis antara $60 \%$ sampai dengan $80 \%$, dan 13 bank BPD konsisten selama 3 tahun berturutturut berada dalam kategori nilai efisien secara teknis dibawah $60 \%$. Sisanya terjadi perubahan kategori efisiensi teknis pada 9 bank BPD selama 3 tahun periode penelitian.

\section{Saran}

Perlu dilakukan penelitian lanjutan tentang pengukuran tingkat efisiensi alokasi (allocative efficiency) dan efisiensi ekonomi (overall efficiency) dengan memanfaatkan pendekatan yang sama agar dapat memberikan makna lebih baik kepada ekonomi dan industri. Dan penelitian efisiensi teknis dengan pendekatan berbeda dalam memilih variabel input dan output.

\section{DAFTAR PUSTAKA}

Abidin, Z, 2007, Kinerja Efisiensi pada Bank Umum, Proceeding PESAT (Psikologi, Ekonomi, Sastra, Arsitektur \& Sipil), Vol. 2 ISSN: 1858-2559. 
Aigner, D., Lovell, C.A.K., and Schmidt, P., 1977, Formulation and estimation of stochastic frontier production functions models. Journal of Econometrics 6; 21-37.

Angelidis, D., Lyroudi, K., 2006, Efficiency in the Italian Banking Industry: Data Envelopment Analysis and neural Networks. International Research Journal of Finance and Economics, 5.

Bhagavath, V., , Technical efficiency measurement by data envelopment analysis: an application in transportation, Alliance Journal of Business Research; 60-72.

Charnes, A., Cooper, W.W., and Rhodes, E., 1978, Measuring the efficiency of Decision Making Units. European Journal of Operation Research 2; 429-444.

Farrel, M.J., 1957, The measurement of productive efficiency, Journal of the Royal Statistical Society A 120; 253-281.

Felipe, J., Adams F.G., 2005, A theory of production: The estimation of the Cobb - Douglas Function: A Retrospective View", Eastern Economic Journal, Vol 31, No.: 3.

Hassan, Md.Z., Kamil, A.A., Mustafa, A., dan Batten, Md.A., 2012, A Cobb - Douglas Stochastic Frontier Model on Measuring Domestic Bank Efficiency in Malaysia, PLOS ONE, Vol. 7, Issues 8, e42215.

Sutawijaya A., Lestari, E.P., 2009. Efisiensi Teknis perbankan Indonesia pasca krisis ekonomi: Sebuah studi empiris penerapan model data envelopment analysis, Jurnal Ekonomi Pembangunan, 10(1) Juni 2009.

Wang, Y.M., Chin, K.S., Yang, J.B., 2007, Measuring the performance of decision making unit using geometric average efficiency, Journal of the Operational Research Society 58; 929937.

Laporan Tahunan Bank Pembangunan Daerah tahun 2009, 2010, dan 2011 yang telah dipublikasikan dalam situs resmi milik Bank Indonesia http://www.bi.go.id/ dan Otoritas Jasa Keuangan http://www.ojk.go.id/ 


\section{Lampiran 1}

Jlka diketahui

$\lambda_{12 k} K_{1}+\mu_{12 k} K_{2}=K_{k}$

$\lambda_{12 k} L_{1}+\mu_{12 k} L_{2}=L_{k}$

maka solusi programasi linier diatas dapat diperoleh dengan mengubah susunan programasi linier diatas menjadi persamaan matriks sebagai berikut

$$
\begin{aligned}
\left(\begin{array}{ll}
K_{1} & K_{2} \\
L_{1} & L_{2}
\end{array}\right)\left(\begin{array}{l}
\lambda_{12 k} \\
\mu_{12 k}
\end{array}\right) & =\left(\begin{array}{l}
K_{k} \\
L_{k}
\end{array}\right) \\
\left(\begin{array}{l}
\lambda_{12 k} \\
\mu_{12 k}
\end{array}\right) & =\left(\begin{array}{ll}
K_{1} & K_{2} \\
L_{1} & L_{2}
\end{array}\right)^{-1}\left(\begin{array}{l}
K_{k} \\
L_{k}
\end{array}\right)
\end{aligned}
$$

dan solusinya adalah

$\lambda_{12 k}=\frac{\left|\begin{array}{ll}K_{k} & K_{2} \\ L_{k} & L_{2}\end{array}\right|}{\left|\begin{array}{ll}K_{1} & K_{2} \\ L_{1} & L_{2}\end{array}\right|}=\frac{K_{k} L_{2}-K_{2} L_{k}}{K_{1} L_{2}-K_{2} L_{1}} \quad \mu_{12 k}=\frac{\left|\begin{array}{ll}K_{1} & K_{k} \\ L_{1} & L_{k}\end{array}\right|}{\left|\begin{array}{ll}K_{1} & K_{2} \\ L_{1} & L_{2}\end{array}\right|}=\frac{K_{1} L_{K}-K_{k} L_{1}}{K_{1} L_{2}-K_{2} L_{1}}$

Jika titik $P_{k}$ terletak pada segmen $P_{1} P_{2}$ maka

$\lambda_{12 k}+\mu_{12 k}=\frac{K_{k} L_{2}-K_{2} L_{k}}{K_{1} L_{2}-K_{2} L_{1}}+\frac{K_{1} L_{K}-K_{k} L_{1}}{K_{1} L_{2}-K_{2} L_{1}}=\frac{\left(K_{1}-K_{2}\right) L_{k}+\left(L_{2}-L_{1}\right) K_{k}}{K_{1} L_{2}-K_{2} L_{1}}$

Kini kita tinjau segmen $P_{1} P_{2}$ yang tidak lain adalah sebuah garis lurus dengan persamaan

$L=\frac{L_{2}-L_{1}}{K_{2}-K_{1}}\left(K-K_{1}\right)+L_{1}$

dan titik $P_{k}$ karena terletak pada segmen $P_{1} P_{2}$ maka memenuhi

$L_{k}=\frac{L_{2}-L_{1}}{K_{2}-K_{1}}\left(K_{k}-K_{1}\right)+L_{1}$

sehingga haruslah

$\lambda_{12 k}+\mu_{12 k}=\frac{-L_{1} K_{2}+L_{2} K_{1}}{K_{1} L_{2}-K_{2} L_{1}}=1$

Jika segmen $P_{1} P_{2}$ terletak antara titik $P_{k}$ dan titik awal koordinat $O(0,0)$ maka terdapat $P^{\prime}{ }_{k}$ yang terletak pada garis $O P_{k}$ yang menghubungkan titik awal koordinat $O(0,0)$ dan titik $P_{k}$ sedemikian hingga $P^{\prime}{ }_{k}$ terletak pada segmen $P_{1} P_{2}$ dan memenuhi

$\lambda_{12 k}+\mu_{12 k}=\frac{K^{\prime}{ }_{k} L_{2}-K_{2} L^{\prime}{ }_{k}}{K_{1} L_{2}-K_{2} L_{1}}+\frac{K_{1} L^{\prime}{ }^{\prime}-K^{\prime}{ }_{k} L_{1}}{K_{1} L_{2}-K_{2} L_{1}}=\frac{\left(K_{1}-K_{2}\right) L^{\prime}{ }_{k}+\left(L_{2}-L_{1}\right) K^{\prime}{ }_{k}}{K_{1} L_{2}-K_{2} L_{1}}$

dan

$L_{k}^{\prime}=\frac{L_{2}-L_{1}}{K_{2}-K_{1}}\left(K^{\prime}{ }_{k}-K_{1}\right)+L_{1}$

Karena segmen $P_{1} P_{2}$ terletak antara titik $P_{k}$ dan titik awal koordinat $O(0,0)$ maka jelas kedudukan $P^{\prime}{ }_{k}$ ada disebelah kiri $P_{k}$ sehingga $K_{k}=K^{\prime}{ }_{k}+\Delta K_{k}$ dan $L_{k}=L^{\prime}{ }_{k}+\Delta L_{k}$ dengan $\Delta K_{k}>0$ dan $\Delta L_{k}>$ 0 sehingga

$\lambda_{12 k}+\mu_{12 k}=\frac{\left(K_{1}-K_{2}\right)\left(K_{k}\right)+\left(L_{2}-L_{1}\right)\left(L_{k}\right)}{K_{1} L_{2}-K_{2} L_{1}}-\frac{\left(L_{2}-L_{1}\right)\left(\Delta L_{k}\right)+\left(K_{1}-K_{2}\right)\left(\Delta K_{k}\right)}{K_{1} L_{2}-K_{2} L_{1}}=1$

$\lambda^{*}{ }_{12 k}+\mu^{*}{ }_{12 k}=\frac{\left(K_{1}-K_{2}\right)\left(K_{k}\right)+\left(L_{2}-L_{1}\right)\left(L_{k}\right)}{K_{1} L_{2}-K_{2} L_{1}}=1+\frac{\left(L_{2}-L_{1}\right)\left(\Delta L_{k}\right)+\left(K_{1}-K_{2}\right)\left(\Delta K_{k}\right)}{K_{1} L_{2}-K_{2} L_{1}}>1$

Jadi bila segmen $P_{1} P_{2}$ terletak antara titik $P_{k}$ dan titik awal koordinat $O(0,0)$ maka penjumlahan $\lambda^{*}{ }_{12 k}+\mu^{*}{ }_{12 k}>1$ 


\section{Lampiran 2}

Tabel-01

Data Labor, Modal dan Kredit

\begin{tabular}{|c|c|c|c|c|c|c|c|c|c|c|c|}
\hline \multirow[b]{2}{*}{ No } & \multirow[b]{2}{*}{ BPD } & \multirow[b]{2}{*}{ Thn } & \multicolumn{2}{|c|}{ Input } & \multirow{2}{*}{$\begin{array}{c}\text { Output } \\
\text { Kredit (Y) } \\
\text { (Rp juta) }\end{array}$} & \multirow[b]{2}{*}{ No } & \multirow[b]{2}{*}{ BPD } & \multirow[b]{2}{*}{ Thn } & \multicolumn{2}{|c|}{ Input } & \multirow{2}{*}{$\begin{array}{c}\text { Output } \\
\text { Kredit (Y) } \\
\text { (Rp juta) }\end{array}$} \\
\hline & & & $\begin{array}{c}\text { Labor (L) } \\
\text { (orang) }\end{array}$ & $\begin{array}{c}\text { Capital (K) } \\
\text { (Rp juta) }\end{array}$ & & & & & $\begin{array}{c}\text { Labor (L) } \\
\text { (orang) }\end{array}$ & $\begin{array}{c}\text { Capital (K) } \\
\text { (Rp juta) }\end{array}$ & \\
\hline 1 & BPD 1 & 2009 & 313 & 20,178 & 517,818 & 40 & BPD 12 & 2010 & 942 & 139,108 & $3,944,684$ \\
\hline 2 & BPD 1 & 2010 & 348 & 21,900 & 542,612 & 41 & BPD 14| & 2011 & 1,079 & 144,715 & $7,273,552$ \\
\hline 3 & BPD 1 & 2011 & 373 & 23,095 & 565,842 & 42 & BPD 13 & 2010 & 1,483 & 151,913 & $7,115,543$ \\
\hline 4 & BPD 2 & 2009 & 414 & 34,262 & $1,143,123$ & 43 & BPD 15 & 2010 & 519 & 159,414 & $2,260,000$ \\
\hline 5 & BPD 2 & 2010 & 430 & 38,373 & $1,317,390$ & 44 & BPD 12 & 2011 & 1,177 & 169,205 & $4,796,976$ \\
\hline 6 & BPD 3 & 2009 & 809 & 38,604 & $2,237,999$ & 45 & BPD 13 & 2011 & 1,662 & 172,361 & $9,211,945$ \\
\hline 7 & BPD 2 & 2011 & 436 & 41,114 & $1,615,625$ & 46 & BPD 15 & 2011 & 1,194 & 182,120 & $2,908,443$ \\
\hline 8 & BPD 4 & 2009 & 306 & 41,326 & 865,129 & 47 & BPD 16 & 2010 & 1,013 & 184,907 & $4,371,300$ \\
\hline 9 & BPD 5 & 2009 & 506 & 44,423 & $1,286,310$ & 48 & BPD 17 & 2009 & 1,684 & 185,924 & $6,278,943$ \\
\hline 10 & BPD 5 & 2010 & 570 & 48,345 & $1,525,941$ & 49 & BPD 16 & 2011 & 1,037 & 187,736 & $5,133,135$ \\
\hline 11 & BPD 5 & 2011 & 687 & 51,835 & $1,956,893$ & 50 & BPD $17 \mid$ & 2010 & 1,744 & 210,564 & $7,259,317$ \\
\hline 12 & BPD 6 & 2009 & 421 & 52,390 & $1,399,218$ & 51 & BPD 18 & 2009 & 888 & 211,080 & $7,280,702$ \\
\hline 13 & BPD 4 & 2010 & 342 & 53,025 & 948,480 & 52 & BPD 19 & 2009 & 889 & 222,309 & $2,799,709$ \\
\hline 14 & BPD 7 & 2009 & 337 & 54,384 & $1,203,624$ & 53 & BPD 18 & 2010 & 1,142 & 238,837 & $9,464,339$ \\
\hline 15 & BPD 4 & 2011 & 435 & 58,931 & $1,236,979$ & 54 & BPD 17 & 2011 & 1,762 & 242,627 & $8,691,732$ \\
\hline 16 & BPD 7 & 2010 & 329 & 58,956 & $1,035,728$ & 55 & BPD 20| & 2009 & 2,141 & 243,261 & $10,124,280$ \\
\hline 17 & BPD 7 & 2011 & 380 & 60,340 & $1,320,176$ & 56 & BPD 19 & 2010 & 1,477 & 261,302 & $3,767,467$ \\
\hline 18 & BPD 6 & 2010 & 476 & 62,121 & $1,692,166$ & 57 & BPD 20 & 2010 & 2,078 & 272,232 & $13,088,127$ \\
\hline 19 & BPD 8 & 2009 & 632 & 63,433 & $1,656,331$ & 58 & BPD 21 & 2009 & 1,560 & 276,631 & $6,395,137$ \\
\hline 20 & BPD 8 & 2010 & 586 & 68,466 & $2,023,907$ & 59 & BPD 18 & 2011 & 1,177 & 277,515 & $11,529,800$ \\
\hline 21 & BPD 6 & 2011 & 516 & 69,111 & $1,996,984$ & 60 & BPD 19 & 2011 & 1,477 & 310,938 & $5,220,031$ \\
\hline 22 & BPD 8 & 2011 & 612 & 83,749 & $2,711,056$ & 61 & BPD 22 & 2009 & 981 & 318,130 & $7,003,505$ \\
\hline 23 & BPD 9 & 2009 & 294 & 83,998 & $1,418,734$ & 62 & BPD 21 & 2010 & 1,595 & 318,586 & $8,161,230$ \\
\hline 24 & BPD 10 & 2009 & 493 & 97,607 & $2,399,505$ & 63 & BPD 23 & 2009 & 1,488 & 321,658 & $8,387,920$ \\
\hline 25 & BPD 9 & 2010 & 514 & 103,648 & $1,721,064$ & 64 & BPD 21 & 2011 & 1,595 & 330,146 & $9,198,871$ \\
\hline 26 & BPD 3 & 2010 & 908 & 103,895 & $3,044,430$ & 65 & BPD 24 & 2009 & 2,784 & 334,010 & $10,691,600$ \\
\hline 27 & BPD 11 & 2009 & 640 & 106,480 & $2,819,843$ & 66 & BPD 22 & 2010 & 1,773 & 340,039 & $8,690,921$ \\
\hline 28 & BPD 12 & 2009 & 844 & 106,945 & $3,095,020$ & 67 & BPD 20 & 2011 & 2,346 & 369,053 & $16,135,173$ \\
\hline 29 & BPD 10 & 2010 & 722 & 109,982 & $2,920,014$ & 68 & BPD 25| & 2009 & 1,291 & 370,680 & $5,198,978$ \\
\hline 30 & BPD 11 & 2010 & 768 & 113,906 & $2,874,494$ & 69 & BPD 22 & 2011 & 1,773 & 379,680 & $10,855,320$ \\
\hline 31 & BPD 3 & 2011 & 944 & 114,280 & $3,686,071$ & 70 & BPD 24 & 2010 & 2,342 & 399,993 & $11,768,141$ \\
\hline 32 & BPD 9 & 2011 & 510 & 114,457 & $1,991,436$ & 71 & BPD 25 & 2010 & 1,522 & 415,873 & $6,634,350$ \\
\hline 33 & BPD 13 & 2009 & 809 & 115,265 & $5,910,683$ & 72 & BPD 23 & 2010 & 1,748 & 421,821 & $9,571,221$ \\
\hline 34 & BPD 14 & 2010 & 1,013 & 124,668 & $6,261,201$ & 73 & BPD 24 & 2011 & 2,275 & 437,986 & $13,606,637$ \\
\hline 35 & BPD 14 & 2009 & 1,062 & 126,242 & $5,951,950$ & 74 & BPD 23 & 2011 & 2,192 & 481,256 & $11,885,386$ \\
\hline 36 & BPD 15 & 2009 & 609 & 127,751 & $1,945,984$ & 75 & BPD 25 & 2011 & 1,667 & 681,954 & $8,310,876$ \\
\hline 37 & BPD 10 & 2011 & 803 & 130,501 & $3,539,845$ & 76 & BPD 26 & 2009 & 2,074 & 879,769 & $19,631,968$ \\
\hline 38 & |BPD 11 & 2011 & 768 & 135,665 & $3,807,784$ & 77 & BPD $26 \mid$ & 2010 & 2,048 & 970,407 & $22,066,317$ \\
\hline 39 & BPD 16 & 2009 & 674 & 137,401 & $3,385,767$ & 78 & BPD 26 & 2011 & 2,127 & $1,053,153$ & $26,998,466$ \\
\hline
\end{tabular}

Sumber data : Bank Indonesia dan Otoritas Jasa Keuangan 
Tabel-02

Data Variabel Faktor Input Labor dan Faktor Input, Modal

\begin{tabular}{|c|c|c|c|c|c|c|c|c|c|}
\hline \multirow[b]{2}{*}{ No } & \multirow[b]{2}{*}{ BPD } & \multirow[b]{2}{*}{ Thn } & \multicolumn{2}{|c|}{ Input } & \multirow[b]{2}{*}{ No } & \multirow[b]{2}{*}{ BPD } & \multirow[b]{2}{*}{ Thn } & \multicolumn{2}{|c|}{ Input } \\
\hline & & & $\begin{array}{c}\mathbf{W}(\mathrm{L} / \mathrm{Y}) \\
\text { (orang/Rp juta) }\end{array}$ & $\begin{array}{c}\mathbf{U}(\mathbf{K} / \mathbf{Y}) \\
\text { (orang/Rp juta) }\end{array}$ & & & & $\begin{array}{c}\mathrm{W}(\mathrm{L} / \mathrm{Y}) \\
\text { (orang/Rp juta) }\end{array}$ & $\begin{array}{c}\mathbf{U}(\mathrm{K} / \mathrm{Y}) \\
\text { (orang/Rp juta) }\end{array}$ \\
\hline 1 & BPD 1 & 2009 & $6.0446 \mathrm{E}-04$ & $3.8967 \mathrm{E}-02$ & 40 & BPD 12 & 2010 & $2.3880 \mathrm{E}-04$ & $3.5265 \mathrm{E}-02$ \\
\hline 2 & BPD 1 & 2010 & $6.4134 \mathrm{E}-04$ & $4.0360 \mathrm{E}-02$ & 41 & BPD 14 & 2011 & $1.4835 \mathrm{E}-04$ & $1.9896 \mathrm{E}-02$ \\
\hline 3 & BPD 1 & 2011 & $6.5919 \mathrm{E}-04$ & $4.0815 \mathrm{E}-02$ & 42 & BPD 13 & 2010 & $2.0842 E-04$ & $2.1349 \mathrm{E}-02$ \\
\hline 4 & BPD 2 & 2009 & 3.6217E-04 & $2.9972 \mathrm{E}-02$ & 43 & BPD 15 & 2010 & $2.2965 \mathrm{E}-04$ & $7.0537 \mathrm{E}-02$ \\
\hline 5 & BPD 2 & 2010 & 3.2640E-04 & $2.9128 \mathrm{E}-02$ & 44 & BPD 12 & 2011 & $2.4536 \mathrm{E}-04$ & $3.5273 \mathrm{E}-02$ \\
\hline 6 & BPD 3 & 2009 & 3.6148E-04 & $1.7249 \mathrm{E}-02$ & 45 & BPD 13 & 2011 & $1.8042 E-04$ & $1.8711 \mathrm{E}-02$ \\
\hline 7 & BPD 2 & 2011 & $2.6986 \mathrm{E}-04$ & $2.5448 \mathrm{E}-02$ & 46 & BPD 15 & 2011 & $4.1053 \mathrm{E}-04$ & $6.2618 \mathrm{E}-02$ \\
\hline 8 & BPD 4 & 2009 & $3.5370 \mathrm{E}-04$ & $4.7769 \mathrm{E}-02$ & 47 & BPD 16 & 2010 & $2.3174 \mathrm{E}-04$ & $4.2300 \mathrm{E}-02$ \\
\hline 9 & BPD 5 & 2009 & 3.9337E-04 & $3.4535 \mathrm{E}-02$ & 48 & BPD 17| & 2009 & $2.6820 \mathrm{E}-04$ & $2.9611 \mathrm{E}-02$ \\
\hline 10 & BPD 5 & 2010 & $3.7354 \mathrm{E}-04$ & $3.1682 \mathrm{E}-02$ & 49 & BPD 16 & 2011 & $2.0202 E-04$ & $3.6573 \mathrm{E}-02$ \\
\hline 11 & BPD 5 & 2011 & 3.5107E-04 & $2.6488 \mathrm{E}-02$ & 50 & BPD 17 & 2010 & $2.4024 \mathrm{E}-04$ & $2.9006 \mathrm{E}-02$ \\
\hline 12 & BPD 6 & 2009 & $3.0088 \mathrm{E}-04$ & $3.7442 \mathrm{E}-02$ & 51 & BPD 18 & 2009 & $1.2197 \mathrm{E}-04$ & $2.8992 \mathrm{E}-02$ \\
\hline 13 & BPD 4 & 2010 & 3.6058E-04 & $5.5905 \mathrm{E}-02$ & 52 & BPD 19 & 2009 & 3.1753E-04 & $7.9404 \mathrm{E}-02$ \\
\hline 14 & BPD 7 & 2009 & $2.7999 \mathrm{E}-04$ & 4.5184E-02 & 53 & BPD 18 & 2010 & $1.2066 \mathrm{E}-04$ & $2.5235 \mathrm{E}-02$ \\
\hline 15 & BPD 4 & 2011 & $3.5166 \mathrm{E}-04$ & $4.7641 \mathrm{E}-02$ & 54 & BPD 17 & 2011 & $2.0272 \mathrm{E}-04$ & $2.7915 \mathrm{E}-02$ \\
\hline 16 & BPD 7 & 2010 & $65 \mathrm{E}-04$ & $2 \mathrm{E}-02$ & 55 & BPD 20 & 2009 & 47E-04 & 027E-02 \\
\hline 17 & BPD 7 & 2011 & $2.8784 \mathrm{E}-04$ & $4.5706 \mathrm{E}-02$ & 56 & BPD 19 & 2010 & $3.9204 \mathrm{E}-04$ & $6.9357 \mathrm{E}-02$ \\
\hline 18 & BPD 6 & 2010 & $2.8130 \mathrm{E}-04$ & $3.6711 \mathrm{E}-02$ & 57 & BPD 20 & 2010 & $1.5877 \mathrm{E}-04$ & $2.0800 \mathrm{E}-02$ \\
\hline 19 & BPD 8 & 2009 & 3.8157E-04 & 3.8297E-02 & 58 & BPD 21 & 2009 & $2.4394 \mathrm{E}-04$ & $4.3256 \mathrm{E}-02$ \\
\hline 20 & BPD 8 & 2010 & 2.8954E-04 & $3829 \mathrm{E}-02$ & 59 & BPD 18 & 2011 & $1.0208 \mathrm{E}-04$ & $2.4069 \mathrm{E}-02$ \\
\hline 21 & BPD 6 & 2011 & $2.5839 \mathrm{E}-04$ & $08 \mathrm{E}-02$ & 60 & BPD 19 & 2011 & $295 \mathrm{E}-04$ & $566 \mathrm{E}-02$ \\
\hline 22 & BPD 8 & 2011 & $2.2574 \mathrm{E}-04$ & 3.0892E-02 & 61 & BPD 22 & 2009 & $1.4007 \mathrm{E}-04$ & $24 \mathrm{E}-02$ \\
\hline 23 & BPD 9 & 2009 & $2.0723 \mathrm{E}-04$ & $5.9206 \mathrm{E}-02$ & 62 & BPD 21 & 2010 & $1.9544 \mathrm{E}-04$ & $3.9037 \mathrm{E}-02$ \\
\hline 24 & BPD 10 & 2009 & $2.0546 \mathrm{E}-04$ & $4.0678 \mathrm{E}-02$ & 63 & BPD 23 & 2009 & $1.7740 \mathrm{E}-04$ & $3.8348 \mathrm{E}-02$ \\
\hline 25 & BPD 9 & 2010 & $2.9865 E-04$ & $6.0223 \mathrm{E}-02$ & 64 & BPD 21 & 2011 & $1.7339 \mathrm{E}-04$ & $3.5890 \mathrm{E}-02$ \\
\hline 26 & BPD 3 & 2010 & 2.9825E-04 & $3.4126 \mathrm{E}-02$ & 65 & BPD 24 & 2009 & $2.6039 \mathrm{E}-04$ & $3.1240 \mathrm{E}-02$ \\
\hline 27 & BPD 11 & 2009 & $2.2696 \mathrm{E}-04$ & 3.7761E-02 & 66 & BPD 22 & 2010 & $2.0401 \mathrm{E}-04$ & $3.9126 \mathrm{E}-02$ \\
\hline 28 & BPD 12 & 2009 & $2.7270 \mathrm{E}-04$ & $3.4554 \mathrm{E}-02$ & 67 & BPD 20 & 2011 & $1.4540 \mathrm{E}-04$ & $2.2873 \mathrm{E}-02$ \\
\hline 29 & BPD 10 & 2010 & $2.4726 \mathrm{E}-04$ & $3.7665 \mathrm{E}-02$ & 68 & BPD 25 & 2009 & $2.4832 \mathrm{E}-04$ & $7.1299 \mathrm{E}-02$ \\
\hline 30 & BPD 11 & 2010 & $2.6718 \mathrm{E}-04$ & $3.9626 \mathrm{E}-02$ & 69 & BPD 22 & 2011 & $1.6333 \mathrm{E}-04$ & $3.4976 \mathrm{E}-02$ \\
\hline 31 & BPD 3 & 2011 & $2.5610 \mathrm{E}-04$ & 3.1003E-02 & 70 & BPD 24 & 2010 & $1.9901 \mathrm{E}-04$ & $3.3989 \mathrm{E}-02$ \\
\hline 32 & BPD 9 & 2011 & $2.5610 \mathrm{E}-04$ & $5.7475 \mathrm{E}-02$ & 71 & BPD 25 & 2010 & $2.2941 \mathrm{E}-04$ & $6.2685 \mathrm{E}-02$ \\
\hline 33 & BPD 13 & 2009 & 1.3687E-04 & 1.9501E-02 & 72 & BPD 23 & 2010 & $1.8263 \mathrm{E}-04$ & $4.4072 \mathrm{E}-02$ \\
\hline 34 & BPD 14 & 2010 & 1.6179E-04 & 1.9911E-02 & 73 & BPD 24 & 2011 & $1.6720 \mathrm{E}-04$ & $3.2189 \mathrm{E}-02$ \\
\hline 35 & BPD 14 & 2009 & $1.7843 \mathrm{E}-04$ & $2.1210 \mathrm{E}-02$ & 74 & BPD 23 & 2011 & $1.8443 \mathrm{E}-04$ & $4.0491 \mathrm{E}-02$ \\
\hline 36 & BPD 15 & 2009 & 3.1295E-04 & $6.5649 \mathrm{E}-02$ & 75 & BPD 25 & 2011 & $2.0058 \mathrm{E}-04$ & $8.2056 \mathrm{E}-02$ \\
\hline 37 & BPD 10 & 2011 & 2.2685E-04 & $3.6866 \mathrm{E}-02$ & 76 & BPD 26 & 2009 & $1.0564 \mathrm{E}-04$ & $4.4813 \mathrm{E}-02$ \\
\hline 38 & BPD 11 & 2011 & $2.0169 \mathrm{E}-04$ & $3.5628 \mathrm{E}-02$ & 77 & BPD 26 & 2010 & $9.2811 \mathrm{E}-05$ & 4.3977E-02 \\
\hline 39 & BPD 16 & 2009 & 1.9907E-04 & $4.0582 \mathrm{E}-02$ & 78 & BPD 26 & 2011 & $7.8782 \mathrm{E}-05$ & $3.9008 \mathrm{E}-02$ \\
\hline
\end{tabular}

Sumber data : Data Diolah dari Bank Indonesia dan Otoritas Jasa Keuangan 


\section{Lampiran 3 : Hasil Regresi Linier}

\begin{tabular}{|c|c|c|c|c|c|}
\hline \multicolumn{4}{|c|}{ Correlations } & & \\
\hline & & KL & $\mathrm{CL}$ & & \\
\hline \multirow{2}{*}{ Pearson Correlation } & KL & 1.0000 & 0.6830 & & \\
\hline & $\mathrm{CL}$ & 0.6830 & 1.0000 & & \\
\hline \multirow{2}{*}{ Sig. (1-tailed) } & KL & & 0.0000 & & \\
\hline & $\mathrm{CL}$ & 0.0000 & & & \\
\hline \multirow{2}{*}{$\mathbf{N}$} & $\mathbf{K L}$ & 78 & 78 & & \\
\hline & $\mathrm{CL}$ & 78 & 78 & & \\
\hline \multicolumn{5}{|c|}{ Model Summaryb } & \\
\hline Model & $\mathbf{R}$ & R Square & $\begin{array}{l}\text { Adjusted R } \\
\text { Square }\end{array}$ & $\begin{array}{l}\text { Std. Error of } \\
\text { the Estimate }\end{array}$ & \\
\hline 1 & $.683 a$ & 0.4670 & 0.4600 & 1486.7675 & \\
\hline \multicolumn{5}{|c|}{ Change Statistics } & Durbin- \\
\hline R Square Change & F Change & df1 & df2 & Sig. F Change & Watson \\
\hline 0.4670 & 66.4700 & 1 & 76 & 0 & 2.1860 \\
\hline
\end{tabular}

a Predictors: (Constant), CL

b Dependent Variable: KL

\begin{tabular}{|c|c|c|c|c|c|c|}
\hline \multicolumn{7}{|c|}{ ANOVAa } \\
\hline Model & & $\begin{array}{c}\text { Sum of } \\
\text { Squares }\end{array}$ & df & Mean Square & $\mathrm{F}$ & Sig. \\
\hline 1 & Regression & $146,931,160.47$ & 1 & $146,931,160.47$ & 66.4700 & $.000 \mathrm{~b}$ \\
\hline & Residual & $167,996,303.75$ & 76 & $2,210,477.68$ & & \\
\hline & Total & $314,927,464.22$ & 77 & & & \\
\hline
\end{tabular}

a Dependent Variable: KL

b Predictors: (Constant), $\mathrm{CL}$

Coefficientsa

\begin{tabular}{|c|c|c|c|c|c|c|}
\hline \multicolumn{7}{|c|}{ Coefficientsa } \\
\hline \multicolumn{2}{|l|}{ Model } & \multicolumn{2}{|c|}{ Unstandardized Coefficients } & \multirow{2}{*}{\begin{tabular}{|c|}
$\begin{array}{l}\text { Standardized } \\
\text { Coefficients }\end{array}$ \\
Beta \\
\end{tabular}} & \multirow[t]{2}{*}{$t$} & \multirow[t]{2}{*}{ Sig. } \\
\hline & & B & Std. Error & & & \\
\hline & (Constant) & 1845.3890 & 379.4630 & & 4.8630 & 0.0000 \\
\hline \multicolumn{2}{|c|}{$\mathrm{CL}$} & 15.8110 & 1.9390 & 0.6830 & 8.1530 & 0.0000 \\
\hline 95.0\% Confidence & Interval for B & \multicolumn{3}{|c|}{ Correlations } & \multicolumn{2}{|c|}{ Collinearity Statistics } \\
\hline Lower Bound & Upper Bound & Zero-order & Partial & Part & Tolerance & VIF \\
\hline 1089.6230 & 2601.1560 & & & & & \\
\hline 11.9480 & 19.6730 & 0.6830 & 0.6830 & 0.6830 & 1 & 1 \\
\hline
\end{tabular}

a Dependent Variable: KL

Collinearity Diagnosticsa

\begin{tabular}{|r|r|r|r|r|r|}
\hline \multicolumn{7}{|c|}{ Collinearity Diagnosticsa } \\
\hline \multirow{2}{*}{ Model } & \multirow{2}{*}{ Dimension } & \multirow{2}{*}{ Eigenvalue } & \multirow{2}{*}{$\begin{array}{c}\text { Condition } \\
\text { Index }\end{array}$} & \multicolumn{2}{c|}{ Variance Proportions } \\
\cline { 5 - 7 } & & & & (Constant) & \multicolumn{1}{c|}{$\mathrm{CL}$} \\
\hline & 1 & 1.8960 & 1.0000 & 0.0500 & 0.0500 \\
\hline & 2 & 0.1040 & 4.2740 & 0.9500 & 0.9500 \\
\hline
\end{tabular}

a Dependent Variable: KL

\begin{tabular}{|l|r|r|r|r|c|}
\hline \multicolumn{7}{|c|}{ Residuals Statisticsa } \\
\hline & \multicolumn{1}{|c|}{ Minimum } & Maximum & \multicolumn{1}{c|}{ Mean } & \multicolumn{1}{l|}{ Std. Deviation } & N \\
\hline Predicted Value & $2,599.8411$ & $9,673.7607$ & $4,618.0208$ & $1,381.3750$ & 78 \\
\hline Std. Predicted Value & -1.4610 & 3.6600 & 0.0000 & 1.0000 & 78 \\
\hline Standard Error of Predicted Value & 168.3620 & 642.5570 & 221.1460 & 88.7360 & 78 \\
\hline Adjusted Predicted Value & $2,592.8042$ & $9,054.1377$ & $4,612.0098$ & $1,352.0466$ & 78 \\
\hline Residual & $-3,327.8154$ & $4,222.6914$ & 0.0000 & $1,477.0816$ & 78 \\
\hline Std. Residual & -2.2380 & 2.8400 & 0.0000 & 0.9930 & 78 \\
\hline Stud. Residual & -2.3670 & 2.8680 & 0.0020 & 1.0130 & 78 \\
\hline Deleted Residual & $-3,721.3811$ & $4,304.6099$ & 6.0110 & $1,539.1811$ & 78 \\
\hline Stud. Deleted Residual & -2.4430 & 3.0170 & 0.0060 & 1.0300 & 78 \\
\hline Mahal. Distance & 0.0000 & 13.3950 & 0.9870 & 2.2850 & 78 \\
\hline Cook's Distance & 0.0000 & 0.5820 & 0.0220 & 0.0760 & 78 \\
\hline Centered Leverage Value & 0.0000 & 0.1740 & 0.0130 & 0.0300 & 78 \\
\hline
\end{tabular}




\section{Lampiran 4 : Hasil Perhitungan Efisiensi}

\begin{tabular}{|c|c|c|c|c|c|c|c|c|c|c|c|c|c|c|}
\hline \multirow{3}{*}{ No } & & & & & & & & $\begin{array}{l}\alpha \\
\mathrm{C}_{0}\end{array}$ & $\begin{array}{r}0.6830 \\
1845.3890\end{array}$ & $\begin{array}{l}B \\
C_{1}\end{array}$ & $\begin{array}{c}\text { \#NUM! } \\
0.6830\end{array}$ & $A_{m a}$ & 6.9896 & \\
\hline & & ahon & In & put & Output & Faktor & Input & Data Re & & & & & & \\
\hline & & Tanun & Labor (L) & Capital (K) & Kredit $(Y)$ & $\mathrm{U}=\mathrm{K} Y \mathrm{Y}$ & $\mathrm{W}=\mathrm{L} / Y$ & $\mathrm{CL}=\mathrm{K} / \mathrm{L}$ & $\mathrm{KL}=\mathrm{Y} / \mathrm{L}$ & A & W/O & $\mathrm{K}_{\mathrm{J}}$ & $\mathrm{K}_{\theta}$ & $\eta=R_{\theta} R_{j}$ \\
\hline 1 & BPD 1 & 2009 & 313 & 20,178 & 517,818 & 0.0390 & 0.0006 & 64.4665 & 1654.3706 & 96.1298 & 0.0155 & 0.0390 & 0.0152 & 0.3892 \\
\hline 2 & BPD 1 & 2010 & 348 & 1,900 & 542,612 & 0.0404 & 0.0006 & 62.9310 & 1559.2299 & 92.1055 & 0.0159 & 0.0404 & 0.0151 & 0.3729 \\
\hline 3 & BPD 1 & 2011 & 373 & 23,095 & 565,842 & 0.0408 & 0.0007 & 61.9169 & 1517.0027 & 90.6110 & 0.0162 & 0.0408 & 0.0150 & 0.3669 \\
\hline 4 & BPD 2 & 2009 & 414 & 34,262 & $1,143,123$ & 0.0300 & 0.0004 & 82.7585 & 2761.1667 & 135.2779 & 0.0121 & 0.0300 & 0.0164 & 0.5477 \\
\hline 5 & BPD 2 & 2010 & 430 & 38,373 & $1,317,390$ & 0.0291 & 0.0003 & 89.2395 & 3063.6977 & 142.5658 & 0.0112 & 0.0291 & 0.0168 & 0.5772 \\
\hline 6 & BPD 3 & 2009 & 809 & 38,604 & $2,237,999$ & 0.0172 & 0.0004 & 47.7182 & 2766.3770 & 197.4105 & 0.0210 & 0.0173 & 0.0138 & 0.7993 \\
\hline 7 & BPD 2 & 2011 & 436 & 41,114 & $1,615,625$ & 0.0254 & 0.0003 & 94.2982 & 3705.5619 & 166.0613 & 0.0106 & .0254 & 0.0171 & 0.6723 \\
\hline 8 & BPD 4 & 2009 & 306 & 41,326 & 865,129 & 0.0478 & 0.0004 & 135.0523 & 2827.2190 & 99.1349 & 0.0074 & 0.0478 & 0.0192 & 0.4014 \\
\hline 9 & BPD 5 & 2009 & 506 & 4,423 & $1,286,310$ & 0.0345 & 0.0004 & 87.7925 & 2542.1146 & 119.6227 & 0.0114 & 0.0345 & 0.0167 & 0.4843 \\
\hline 10 & BPD 5 & 2010 & 570 & 8,345 & 525,941 & 0.0317 & 0.0004 & 84.8158 & 2677.0895 & 28.9773 & 0.0118 & .0317 & 0.0165 & 0.5222 \\
\hline 11 & BPD 5 & 2011 & 687 & 1,835 & $1,956,893$ & 0.0265 & 0.0004 & 75.4512 & 2848.4614 & 148.6498 & 0.0133 & .0265 & 0.0159 & 0.6018 \\
\hline 12 & BPD 6 & 2009 & 421 & 52,390 & $1,399,218$ & 0.0374 & 0.0003 & 124.4418 & 3323.5582 & 123.2371 & 0.0080 & .0374 & 0.0187 & 0.4990 \\
\hline 13 & BPD 4 & 2010 & 342 & 53,025 & 948,480 & 0.0559 & 0.0004 & 155.0439 & 2773.3333 & 88.4956 & 0.0064 & .0559 & 0.0200 & 0.3583 \\
\hline 14 & BPD 7 & 2009 & 337 & 54,384 & $1,203,624$ & 0.0452 & 0.0003 & 161.3769 & 3571.5846 & 110.8933 & 0.0062 & .0452 & 0.0203 & 0.4490 \\
\hline 15 & BPD 4 & 2011 & 435 & 58,931 & $1,236,979$ & 0.0476 & 0.0004 & 135.4736 & 2843.6299 & 99.4985 & 0.0074 & .0476 & 0.0192 & 0.4028 \\
\hline 16 & BPD 7 & 2010 & 329 & 58,956 & $1,035,728$ & 0.0569 & 0.0003 & 179.1976 & 3148.1094 & 90.9964 & 0.0056 & .0569 & 0.0210 & 0.3684 \\
\hline 17 & BPD 7 & 2011 & 380 & 0,340 & $1,320,176$ & 0.0457 & 0.0003 & 158.7895 & 3474.1474 & 109.0654 & 0.0063 & .0457 & 0.0202 & 0.4416 \\
\hline 18 & BPD 6 & 2010 & 476 & 121 & $1,692,166$ & 0.0367 & .0003 & 130.5063 & 3554.9706 & 127.6027 & .0077 & .0367 & 0.0190 & 0.5166 \\
\hline 19 & BPD 8 & 2009 & 632 & 63,433 & $1,656,331$ & 0.0383 & 0.0004 & 100.3687 & 2620.7769 & 112.5482 & 0.0100 & 0.0383 & 0.0175 & 0.4557 \\
\hline 20 & BPD 8 & 2010 & 586 & 68,466 & $2,023,907$ & 0.0338 & 0.0003 & 116.8362 & 3453.7662 & 133.7019 & .0086 & .0338 & 0.0183 & 0.5413 \\
\hline 21 & BPD 6 & 2011 & 516 & 9,111 & $1,996,984$ & 0.0346 & 0.0003 & 133.9360 & 3870.1240 & 136.4753 & 0075 & 0346 & 0.0191 & 0.5526 \\
\hline 22 & BPD 8 & 2011 & 612 & 83,749 & $2,711,056$ & 0.0309 & 0.0002 & 136.8448 & 4429.8301 & 153.9371 & .0073 & .0309 & 0.0193 & 0.6233 \\
\hline 23 & BPD 9 & 2009 & 294 & 3,998 & $1,418,734$ & 0.0592 & 0.0002 & 285.7075 & 4825.6259 & 01.4283 & .0035 & .0592 & 0.0243 & 0.4107 \\
\hline 24 & PD 10 & 2009 & 493 & 97,607 & $2,399,505$ & 0.0407 & 0.0002 & 197.9858 & 4867.1501 & 131.4237 & .0051 & .0407 & 0.0216 & 0.5321 \\
\hline 25 & BPD 9 & 2010 & 514 & 103,648 & $1,721,064$ & 0.0602 & 0.0003 & 201.6498 & 3348.3735 & 89.2881 & .0050 & .0602 & 0.0218 & 0.3615 \\
\hline 26 & PPD 3 & 2010 & 908 & 103,895 & $3,044,430$ & 0.0341 & 0.0003 & 114.4218 & 3352.8965 & 131.6615 & .0087 & .0341 & 0.0182 & 0.5331 \\
\hline 27 & D 11 & 2009 & 640 & 106,480 & $2,819,843$ & 0.0378 & 0.0002 & 166.3750 & 4406.0047 & 33.9806 & .0060 & .0378 & 0.0205 & 0.5425 \\
\hline 28 & DD 12 & 2009 & 844 & 106,945 & $3,095,020$ & 0.0346 & 0.0003 & 126.7121 & 3667.0853 & 134.3063 & .0079 & 0.0346 & 0.0188 & 0.5438 \\
\hline 29 & PD 10 & 2010 & 722 & 109,982 & $2,920,014$ & 0.0377 & 0.0002 & 152.3296 & 4044.3407 & 30.6189 & 0066 & .0377 & 0.0199 & 0.5288 \\
\hline 30 & D 11 & 2010 & 768 & 113,906 & $2,874,494$ & 0.0396 & 0.0003 & 148.3151 & 3742.8307 & 123.1064 & .0067 & .0396 & 0.0198 & 0.4984 \\
\hline 31 & BPD 3 & 2011 & 944 & 114,280 & $3,686,071$ & 0.0310 & 0.0003 & 121.0593 & 3904.7362 & 147.5380 & .0083 & .0310 & 0.0185 & 0.5973 \\
\hline 32 & BPD 9 & 2011 & 10 & 114,457 & $1,991,436$ & 0.0575 & 0003 & 224.4255 & 3904.7765 & 96.7863 & .0045 & 0575 & 0.0225 & 0.3919 \\
\hline 33 & PD 13 & 2009 & 09 & 1 & 5,9 & 0.0195 & 0.0001 & 142.4784 & 7306.1595 & 246.9896 & .0070 & 0195 & 0.0195 & 1.0000 \\
\hline 34 & DD 14 & 2010 & 1,013 & 124,668 & $6,261,201$ & 0.0199 & 0.0002 & 123.0681 & 6180.8500 & 230.9292 & 0.0081 & .0199 & 0.0186 & 0.9350 \\
\hline 35 & D 14 & 2009 & 1,062 & 126,242 & $5,951,950$ & 0.0212 & 0.0002 & 118.8719 & 5604.4727 & 214.4152 & 0.0084 & .0212 & 0.0184 & 0.8681 \\
\hline 36 & D 15 & 2009 & 609 & 127,751 & $1,945,984$ & 0.0656 & 0.0003 & 209.7718 & 3195.3760 & 82.9409 & .0048 & 0.0656 & 0.0220 & 0.3358 \\
\hline 37 & D 10 & 2011 & 803 & 130,501 & $3,539,845$ & 0.0369 & 0.0002 & 162.5168 & 4408.2752 & 136.2151 & .0062 & .0369 & 0.0203 & 0.5515 \\
\hline 38 & PD 11 & 2011 & 768 & 135,665 & $3,807,784$ & 0.0356 & 0.0002 & 176.6471 & 4958.0521 & 144.7229 & .0057 & .0356 & 0.0209 & 0.5859 \\
\hline 39 & PD 16 & 2009 & 674 & 137,401 & $3,385,767$ & 0.0406 & 0.0002 & 203.8591 & 5023.3932 & 132.9612 & 0.0049 & .0406 & 0.0218 & 0.5383 \\
\hline 40 & PD 12 & 2010 & 942 & 139,108 & $3,944,684$ & 0.0353 & 0.0002 & 147.6730 & 4187.5626 & 138.1429 & 0068 & .0353 & 0.0197 & 0.5593 \\
\hline 41 & DD 14 & 2011 & 1,079 & 144,715 & $7,273,552$ & 0.0199 & 0.0001 & 134.1196 & 6741.0120 & 237.4915 & 0075 & .0199 & 0.0191 & 0.9615 \\
\hline 42 & PD 13 & 2010 & 1,483 & 1 & 7, & 0.0213 & 0.0002 & 102.4363 & 4798.0735 & 03.2015 & 0098 & .0214 & 0.0176 & 0.8227 \\
\hline 43 & DD 15 & 2010 & 519 & 159,414 & $2,260,000$ & 0.0705 & 0.0002 & 307.1561 & 4354.5279 & 87.1114 & .0033 & .0705 & 0.0249 & 0.3527 \\
\hline 44 & PD 12 & 2011 & 1,177 & 169,205 & $4,796,976$ & 0.0353 & 0.0002 & 143.7596 & 4075.5956 & 136.9384 & 0.0070 & .0353 & 0.0196 & 0.5544 \\
\hline 45 & DD 13 & 2011 & 1,662 & 172,361 & $9,211,945$ & 0.0187 & 0.0002 & 103.7070 & 5542.6865 & 232.7681 & 0.0096 & 0.0187 & 0.0176 & 0.9424 \\
\hline 46 & D 15 & 2011 & 1,194 & 182,120 & $2,908,443$ & 0.0626 & 0.0004 & 152.5293 & 2435.8819 & 78.6006 & 0.0066 & .0626 & 0.0199 & 0.3182 \\
\hline 47 & DD 16 & 2010 & 1,013 & 184,907 & $4,371,300$ & 0.0423 & 0.0002 & 182.5341 & 4315.2024 & 123.1695 & 0.0055 & .0423 & 0.0211 & 0.4987 \\
\hline 48 & D 17 & 2009 & 1,684 & 185,924 & $6,278,943$ & 0.0296 & 0.0003 & 110.4062 & 3728.5885 & 150.0306 & .0091 & .0296 & 0.0180 & 0.6074 \\
\hline 49 & D 16 & 2011 & 37 & 6 & 35 & 0.0366 & 0.0002 & 181.0376 & 4949.9855 & 142.0849 & 0055 & 0366 & 0.0210 & 0.5753 \\
\hline 50 & D 17 & 2010 & 1,744 & 4 & 7,259 & 0.0290 & 0.0002 & 120.7362 & 4162.4524 & 157.5630 & .0083 & 0290 & 0.0185 & 0.6379 \\
\hline 51 & D 18 & 2009 & 888 & 211,080 & $7,280,702$ & 0.0290 & 0.0001 & 237.7027 & 8198.9887 & 195.4020 & 0.0042 & .0290 & 0.0229 & 0.7911 \\
\hline 52 & D 19 & 2009 & 889 & 222,309 & $2,799,709$ & 0.0794 & 0.0003 & 250.0664 & 3149.2790 & 72.5002 & .0040 & .0794 & 0.0233 & 0.2935 \\
\hline 53 & D 18 & 2010 & 1,142 & 238,837 & $9,464,339$ & 0.0252 & 0.0001 & 209.1392 & 8287.5123 & 215.5593 & 0.0048 & .0252 & 0.0220 & 0.8727 \\
\hline 54 & D 17 & 2011 & 1,762 & 242,627 & $8,691,732$ & 0.0279 & 0.0002 & 137.6998 & 4932.8785 & 170.6904 & 0.0073 & 0.0279 & 0.0193 & 0.6911 \\
\hline 55 & D 20 & 2009 & 2,141 & 243,261 & $10,124,280$ & 0.0240 & 0.0002 & 113.6203 & 4728.7623 & 186.5826 & 0.0088 & .0240 & 0.0182 & 0.7554 \\
\hline 56 & PD 19 & 2010 & 1,477 & 261,302 & $3,767,467$ & 0.0694 & 0.0004 & 176.9140 & 2550.7563 & 74.3785 & 0.0057 & .0694 & 0.0209 & 0.3011 \\
\hline 57 & PD 20 & 2010 & 2,078 & 272,232 & $13,088,127$ & 0.0208 & 0.0002 & 131.0067 & 6298.4249 & 225.4864 & 0.0076 & .0208 & 0.0190 & 0.9129 \\
\hline 58 & D 21 & 2009 & 60 & 631 & 37 & 0.0433 & 0.0002 & 177.3276 & 4099.4468 & 119.3469 & 0.0056 & 0433 & 0.0209 & 0.4832 \\
\hline 59 & PD 18 & 2011 & 77 & 277,515 & $11,529,800$ & 0.0241 & 0.0001 & 235.7816 & 9795.9218 & 234.7583 & 0.0042 & 0241 & 0.0229 & 0.9505 \\
\hline 60 & D 19 & 2011 & 1,477 & 3 & 31 & 0.0596 & 0.0003 & 210.5200 & 3534.2119 & 91.5131 & 0048 & 0596 & 0.0221 & 0.3705 \\
\hline 61 & D 22 & 2009 & 981 & 3 & $7,003,505$ & 0454 & 0 & 2915 & 7139.1488 & 137.6187 & | & 0454 & 0.0253 & 0.5572 \\
\hline 62 & D 21 & 2010 & 1,595 & 3 & $8,161,230$ & 0390 & 002 & 199.7404 & 5116.7586 & 137.3336 & 0050 & .0390 & 0.0217 & 0.5560 \\
\hline 63 & D 23 & 2009 & 1,488 & 1,658 & 887,920 & 0383 & 0.0002 & 216.1680 & 5637.0430 & 43.3471 & .0046 & .0383 & 0.0223 & 0.5804 \\
\hline 64 & D 21 & 2011 & 1,595 & 330,146 & 198,871 & 0.0359 & 0.0002 & 206.9881 & 5767.3172 & 151.0717 & .0048 & .0359 & 0.0220 & 0.6117 \\
\hline 65 & PD 24 & 2009 & 2,784 & 4,010 & $10,691,600$ & 0.0312 & 0.0003 & 119.9749 & 3840.3736 & 146.0007 & .0083 & .0312 & 0.0185 & 0.5911 \\
\hline 66 & PD 22 & 2010 & 1,773 & 340,039 & $8,690,921$ & 0.0391 & 0.0002 & 191.7874 & 4901.8167 & 135.2667 & 0.0052 & .0391 & 0.0214 & 0.5477 \\
\hline 67 & PD 20 & 2011 & 2,346 & 369,053 & $16,135,173$ & 0.0229 & 0.0001 & 157.3116 & 6877.7379 & 217.2992 & 0.0064 & .0229 & 0.0201 & 0.8798 \\
\hline 68 & D 25 & 2009 & 1,291 & 370,680 & 98,978 & 0.0713 & 0.0002 & 287.1263 & 4027.0937 & 84.3583 & .0035 & .0713 & 0.0244 & 0.3415 \\
\hline 69 & $\mathrm{D} 22$ & 2011 & 1,773 & 379,680 & $10,855,320$ & .0350 & 0.0002 & 214.1455 & 6122.5719 & 156.6966 & .0047 & .0350 & 0.0222 & 0.6344 \\
\hline 70 & D 24 & 2010 & 2, & 3 & $11,768,141$ & 0340 & 0002 & 170.7912 & 5024.8254 & 150.0884 & .0059 & 0340 & 0.0207 & 0.6077 \\
\hline 71 & D 25 & 2010 & 22 & 73 & 34,350 & .0627 & .0002 & 3.2411 & 4358.9685 & 4.4545 & .0037 & .0627 & 0.0240 & 0.3824 \\
\hline 72 & $\mathrm{D} 23$ & 2010 & 8 & 21 & 71,221 & 441 & .0002 & 241.3164 & 5475.5269 & 129.1574 & 0041 & 0441 & 0.0230 & 0.522 \\
\hline 73 & PD 24 & 2011 & 2,275 & 437,986 & $13,606,637$ & 0.0322 & 0.0002 & 192.5213 & 5980.9393 & 164.6154 & 0.0052 & .0322 & 0.0215 & 0.6665 \\
\hline 74 & BPD 23 & 2011 & 2,192 & 481,256 & $11,885,386$ & 0.0405 & 0.0002 & 219.5511 & 5422.1651 & 136.4281 & .0046 & .0405 & 0.0224 & 0.552 \\
\hline 75 & PPD 25 & 2011 & 1,667 & & 876 & 0.0821 & 0.0002 & 409.0906 & 4985.5285 & 82.0047 & 0.0024 & 0.0821 & 0.0272 & 0.3320 \\
\hline 76 & BPD 26 & 2009 & 2,074 & 879,769 & $19,631,968$ & 0.0448 & 0.0001 & 424.1895 & 9465.7512 & 151.8909 & 0.0024 & 0.0448 & 0.0276 & 0.6150 \\
\hline 77 & BPD 26 & 2010 & 2,048 & 970,407 & $22,066,317$ & 0.0440 & 0.0001 & 473.8315 & 10774.5688 & 160.3056 & 0.0021 & 0.0440 & 0.0285 & 0.649 \\
\hline 78 & DD 26 & 2011 & 2,127 & $, 053,153$ & $26,998,466$ & 0.0390 & 0.0001 & 495.1354 & 12693.2139 & 183.2631 & 0.0020 & 0.0390 & 0.0289 & 0.742 \\
\hline
\end{tabular}

